\title{
Reviewing the Local and Global Implications of Air Pollution Trends in Zaria, Northern Nigeria
}

\author{
Yahaya A. Aliyu ${ }^{1,3 *}$, Joel O. Botai ${ }^{2,1}$ \\ ${ }^{1}$ Department of Geography, Geoinformatics and Meteorology, University of Pretoria, Pretoria- \\ 0002, South Africa \\ ${ }^{2}$ South African Weather Service, 442 Rigel Avenue South, Erasmusrand, Pretoria-0001, South \\ Africa \\ ${ }^{3}$ Department of Geomatics, Ahmadu Bello University, Zaria, Kaduna-810282, Nigeria \\ *Corresponding author. Tel.: +234-803-464-2728; Email address: u15221408@tuks.co.za
}

\section{Highlights}

- Pioneer outdoor air pollution time-series data for a Nigerian city

- Validates MSA Altair 5× gas detector and CW-HAT200 particulate counter.

- Alarming outdoor pollution measurements

- A candidate into the list of World's most polluted cities is revealed.

\begin{abstract}
Air pollution is an unnoticed problem in many Nigerian urban cities. This is mainly attributed to the usage of power generating sets, indiscriminate refuse burning, biomass consumption and import/recycle of timeworn automobiles, which dominates the Nigerian automobile fleet. Reduced economic infrastructure and the Nigerian climate, are a major factor for the dense outdoor population activities. This is contributing to the increasing population health risk resulting from pollution exposure. Literature on the seasonal spatial-temporal distribution of air pollutants within Nigerian urban cities is presently scanty. This study evaluates the local and global implications of air pollution trends in northern Nigeria's educational hub. The study utilized validated costeffective devices (MSA Altair 5x gas detector and the CW-HAT200 particulate counter) to assess the outdoor air quality in Zaria. The findings revealed the one-year day-time weighted average concentration level for $\mathrm{CO}, \mathrm{SO}_{2} \mathrm{PM}_{2.5}$ and $\mathrm{PM}_{10}$ as $29.22 \mathrm{ppm}, 0.32 \mathrm{ppm}, 219.73$ and $451.96 \mu \mathrm{gm}^{-}$ ${ }^{3}$ respectively. These concentration levels were above the locally and globally stipulated air quality indices. In particular, the concentration levels of the particulate matter pollutants $\left(\mathrm{PM}_{2.5}\right.$ and $\left.\mathrm{PM}_{10}\right)$ were high enough to place Zaria amongst the World Health Organization's list of polluted cities. We are optimistic that our findings would instigate Nigerian policy makers to take decisive steps for air quality management across its cities.
\end{abstract}

Keywords: Air pollution; Air quality index; MSA Altair 5x gas detector; Chinaway CW-HAT200 particulate counter; Nigeria 


\section{Introduction}

Urban air pollution is a major ecological threat in most developing countries (Gorai et al., 2017). The consistent rise in greenhouse gas emissions is also intensifying and therefore affects the earth's climate system (Nsubuga et al., 2013). Studies have expressed concerns over outdoor air pollution especially since the anthropogenic sources in the urban cities are positioned at ground level, thus aggregating exposure profile of the population within (Aliyu et al., 2014; Patton et al., 2016).

In Africa, air quality studies are very challenging especially when it comes to accessing observed station series data. This is due to difficulties regarding the availability, accessibility and consistency of pollution datasets. Some of the cited studies revealed that they depended on remote sensing re-analysis data (e.g. top-down estimates), to fill this gap (DeMott et al., 2003; Hopkins et al., 2009; Marais et al., 2014; Marais and Chance, 2015). Proper management of city-scale air pollution can be complex, especially when there is no accurate and organized geospatial data for up-to-date identification of specie pollutants, distribution of sample sites, regularity/period of sampling, sampling methods, infrastructural amenities, man power and maintenance expenditures (Al-Awadi et al., 2015).

Nigeria is Africa's leading economy. It has a rapidly growing population with little information available about its air quality (Marais et al., 2014). Air pollution is a serious threat to public health in most Nigerian urban cities resulting from poorly managed private/commercial vehicles, unregulated recreational activities, trash burning, traffic congestions and biomass consumption. These often leads to high air pollution from unproductive fuel combustion in the socio-economical scheme (Hopkins et al., 2009; Aliyu et al., 2014). The challenges with urban air pollution in Nigerian urban cities is well-known, however the attitude towards tackling it remains uncertain. Air quality studies across Nigerian cities demonstrate that pollution measurements are collected on makeshift basis and in most cases, the monitoring network is scantily distributed. With such situation, it is therefore difficult to develop an air quality management plan for its cities. To instigate this process, we appraise the ramifications of air quality for northern Nigeria's educational hub, Zaria.

The Intergovernmental Panel on Climate Change (IPCC) guideline continues to reflect on the need for policy makers to create emission inventories that are accurate and consistent. This will encourage continuous improvement of emission inventory compilation to international standards (Francesco et al., 2014). For effective air pollution management, there must be collaboration 
between various key sector players including transportation, energy, water resources, urban planning and health (Hasenfratz et al., 2015). In addition, air pollution is usually regulated by air quality guidelines. Presently, organizations and countries e.g. World Health Organization (WHO); South African National Standards (SANS); Nigeria's Federal Environmental Protection Agency (FEPA), have adopted varying air quality indices (AQIs) (Table 1). These AQIs are centred on the ambient concentrations of criteria pollutants including, but not limited to - $\mathrm{CO}$ (Carbon Monoxide), $\mathrm{PM}_{10}$ (Particulate Matter of less than $10 \mu \mathrm{m}$ in aerodynamic diameter) and $\mathrm{SO}_{2}$ (Sulphur Dioxide), while in some cases $\mathrm{PM}_{2.5}$ (less than $2.5 \mu \mathrm{m}$ in aerodynamic diameter) is taken into consideration (Cairncross et al., 2007).

Table 1. Threshold of selected air pollutants, modified after (FEPA, 1999; SANS, 2011; WHO, 2017).

\begin{tabular}{lccc}
\hline Pollutants & \multicolumn{3}{c}{$A Q I s$} \\
\cline { 2 - 4 } & $W H O^{a}$ & $S A N S^{b}$ & $F E P A^{c}$ \\
\hline $\mathrm{CO}$ & $9 \mathrm{ppm}^{-3}$ & $26 \mathrm{ppm}$ & $20 \mathrm{ppm}$ \\
$\mathrm{PM}_{2.5}$ & $25 \mu \mathrm{gm}^{-3}$ & - & - \\
$\mathrm{PM}_{10}$ & $50 \mu \mathrm{gm}^{-3}$ & $75 \mu \mathrm{gm}^{-3}$ & $150 \mu \mathrm{gm}^{-3}$ \\
$\mathrm{SO}_{2}$ & $0.01 \mathrm{ppm}$ & $0.13 \mathrm{ppm}$ & $0.1 \mathrm{ppm}$ \\
\hline
\end{tabular}

a24-hour time weighted average for listed pollutants except $\mathrm{CO}$ (8-hour); ${ }^{\mathrm{b}} 1$-hr time weighted average for listed pollutants; 'time weighted average is not indicated; ppm (parts per million); $\mu \mathrm{gm}^{-3}$ (microgram per meter cube)

\section{Materials and Methods}

\subsection{Study Area}

Zaria metropolis is the educational hub of Northern Nigeria (Figure 1). It occupies an area of approximately $296.04 \mathrm{~km}^{2}$. It has an estimated population of 938, 521 from the 2006 census considering its growth rate of 3.0 percent per year. The study area is stationed at an altitude of mainly about $670 \mathrm{~m}$ above mean sea level (MSL) (NPC, 2010). Its climate is characterized by 2 seasons: dry (October - May) and rainy (June - September). The respective seasonal average values for dry and rainy seasons are: precipitation $(24.6 \mathrm{~mm}$ and $213.8 \mathrm{~mm})$, minimum temperature $\left(14.1^{\circ} \mathrm{C}\right.$ and $\left.19.5^{\circ} \mathrm{C}\right)$ and maximum temperature $\left(35.2^{\circ} \mathrm{C}\right.$ and $\left.28.9^{\circ} \mathrm{C}\right)($ Grace et al., 2015). 


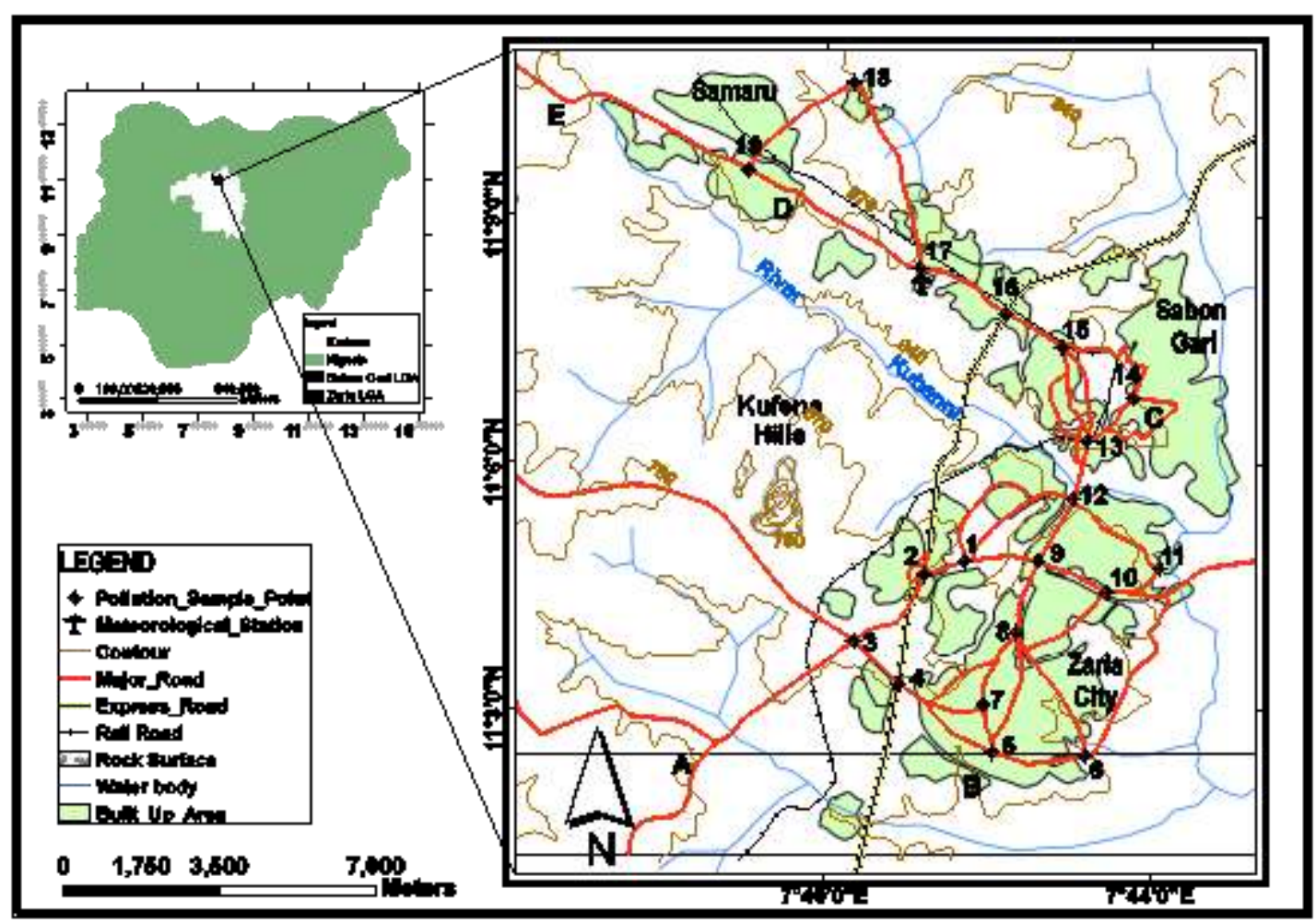

Figure 1. The study area highlighting the distribution of pollution sample sites. The sampling sites are described in Table 2.

Table 2. Description of pollution sample sites

\begin{tabular}{llccc}
\hline S/No & Description & Longitude (deg.) & Latitude (deg.) & $\begin{array}{c}\text { Dense population } \\
\text { activity }\end{array}$ \\
\hline 1 & Kofar Kibo & 7.695 & 11.080 & Yes \\
2 & Danmagaji, Wusasa & 7.686 & 11.078 & Yes \\
3 & Madaci, Saye & 7.673 & 11.064 & No \\
4 & Gwargwaje & 7.682 & 11.054 & Yes \\
5 & Kofar Gayan & 7.701 & 11.044 & Yes \\
6 & Kofar Kona & 7.720 & 11.041 & No \\
7 & Zaria City Market & 7.699 & 11.051 & Yes \\
8 & Babban Dodo & 7.706 & 11.066 & Yes \\
9 & Kofar Doka & 7.710 & 11.081 & Yes \\
10 & Banzazzau & 7.725 & 11.074 & Yes \\
11 & FCE/Ungwan Kaya & 7.735 & 11.079 & Yes \\
12 & Agwaro, Tudun Wada & 7.717 & 11.093 & Yes \\
13 & PZ & 7.721 & 11.104 & Yes \\
14 & Sabon Gari Market & 7.730 & 11.113 & Yes \\
15 & MTD & 7.715 & 11.124 & Yes \\
16 & Kwangila Bridge & 7.703 & 11.130 & Yes \\
17 & Aviation by NITT Road & 7.686 & 11.139 & Yes \\
18 & Basawa by Hayin Dogo & 7.672 & 11.177 & No \\
19 & Samaru Market & 7.651 & 11.159 & Yes \\
\hline
\end{tabular}




\subsection{Method and Instrumentation}

The nineteen sampling sites were identified across study area (Table 2). All the sites are located along major road intersections. 16 sites are positioned within dense population activities which cuts across the residential and commercial settlements, while the remaining 3 control sites are positioned strategically at the outskirts of the city with minimal population activity. The control sites were used to aid in result comparison. The most convenient route across the 19 sample stations for effective cost and timing was identified and tagged serially as $1-19$ (Figure 1). This covers a distance of $42.8 \mathrm{~km}$.

Four criteria air pollutants $\mathrm{CO}, \mathrm{SO}_{2}, \mathrm{PM}_{2.5}$, and $\mathrm{PM}_{10}$ were monitored to achieve study objectives. The MSA Altair 5x gas detector (Figure 2a) and CW-HAT200 particulate counter (Figure 2b) were used to collect ground level pollution concentrations, for December 2015 November 2016. Ground in-situ samples were retrieved daily across three epochs. They are: morning (0730 - $0845 \mathrm{hrs})$, afternoon (1300 - $1415 \mathrm{hrs)}$ and evening (1700 - $1815 \mathrm{hrs})$. The reason for adopting these epochs is to ensure adequate representation of pollution related activities at peak (morning and evening) and less peak (afternoon) periods (Pattinson et al., 2014; Wang et al., 2014; Yazdi et al., 2015). The observed concentration levels for the criteria pollutants were recorded based on instrument configuration (Table 3). To ensure assurance and control of data quality, detectors were calibrated using the procedures described in the producer manual. The instrument background and pump flow were also examined prior to conducting each monitoring session. Pollutant concentration levels for $\mathrm{CO}$ and $\mathrm{SO}_{2}$ were obtained using the MSA Altair $5 \mathrm{x}$ in parts per million (ppm) units, while the CW-HAT200 collected particulate matter $\left(\mathrm{PM}_{2.5}\right.$ and $\left.\mathrm{PM}_{10}\right)$ in microgram per meter cube $\left(\mu \mathrm{g} \mathrm{m}^{-3}\right)$. The day-time observations were collected with devices positioned at $1.5 \mathrm{~m}$ above ground level (average height of an adult).

(a)

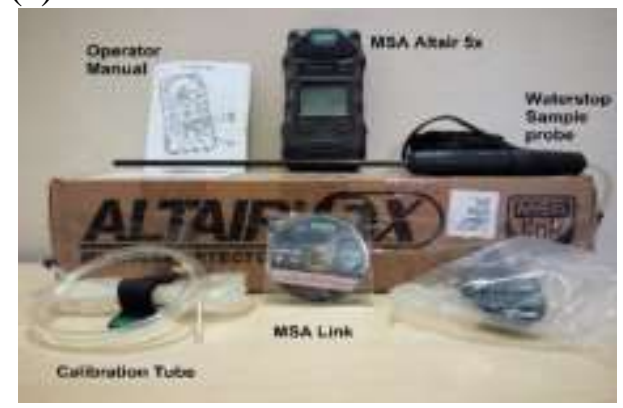

(b)

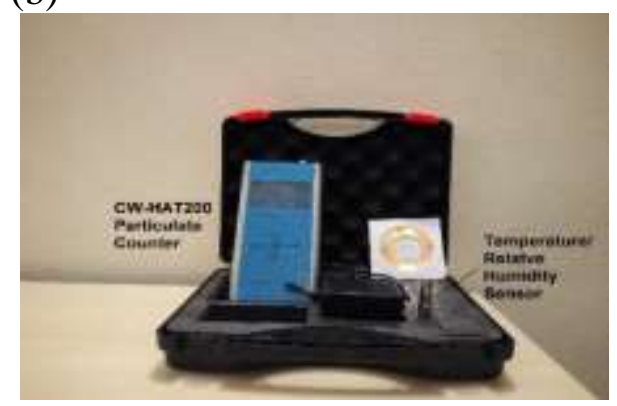

Figure 2. Portable air pollutant detectors (a) MSA Altair 5x gas detector; (b) Chinaway CWHAT200) particulate counter 
Table 3. Specifications of portable pollutant monitors utilized for the study

\begin{tabular}{|c|c|c|}
\hline Specifications & MSA Altair $5 x$ Gas Detector ${ }^{a}$ & $\begin{array}{l}\text { Chinaway CW-HAT200 Particle } \\
\text { Counter }\end{array}$ \\
\hline Dimension $(\mathrm{cm})$ & $17(\mathrm{H}) \times 8.94(\mathrm{~W}) \times 4.88(\mathrm{D})$ & $18(\mathrm{H}) \times 9.3(\mathrm{~W}) \times 4.8(\mathrm{D})$ \\
\hline Weight $(\mathrm{kg})$ & 0.45 & 0.60 \\
\hline Measuring method & $\begin{array}{l}\text { Internal pump; } \\
\text { Catalytic/electrochemical } \\
\text { sensor }\end{array}$ & $\begin{array}{l}\text { Internal pump; laser light } \\
\text { scattering }\end{array}$ \\
\hline Pollutant measured & $\begin{array}{l}\mathrm{CO} ; \mathrm{SO}_{2} ; \mathrm{H}_{2} \mathrm{~S} ; \mathrm{LEL} \\
\text { (Combustible) }\end{array}$ & $\mathrm{PM}_{2.5}, \mathrm{PM}_{10}$ \\
\hline Concentration Range & $\begin{array}{l}\mathrm{CO}(0-500 \mathrm{ppm}) \\
\mathrm{SO}_{2}(0-25 \mathrm{ppm}) \\
\mathrm{H}_{2} \mathrm{~S}(0-100 \mathrm{ppm}) \\
\mathrm{LEL}(0-100 \%)\end{array}$ & $\begin{array}{l}\mathrm{PM}_{2.5}\left(0-500 \mu \mathrm{gm}^{-3}\right) \\
\mathrm{PM}_{10}\left(0-1000 \mu \mathrm{gm}^{-3}\right)\end{array}$ \\
\hline Sample/Response & $\mathrm{CO}(15 \mathrm{secs})$ & $\mathrm{PM}_{2.5}(60$ secs $)$ \\
\hline Time & $\begin{array}{l}\mathrm{SO}_{2}(20 \text { secs }) \\
\mathrm{H}_{2} \mathrm{~S}(15 \text { secs })\end{array}$ & $\mathrm{PM}_{10}(60$ secs $)$ \\
\hline Accuracy & $\pm 10 \%$ of reading & $\pm 5 \%$ of reading \\
\hline Operating temperature & $-10^{\circ} \mathrm{C}$ to $40^{\circ} \mathrm{C}$ & $5{ }^{\circ} \mathrm{C}$ to $45^{\circ} \mathrm{C}$ \\
\hline Operating humidity & $15-90 \% \mathrm{RH}$ & $<90 \% \mathrm{RH}$ \\
\hline Calibration Due & 6 months & 1 year \\
\hline Battery & Rechargeable lithium-ion & $\begin{array}{l}\text { Rechargeable lithium-ion } \\
\text { polymer }\end{array}$ \\
\hline Display & Monochrome & LCD \\
\hline Certification & CE, UL, CSA, IEC, IP & $\mathrm{CE}$ \\
\hline
\end{tabular}

${ }^{a}$ Instrument re-calibration was carried out in January 2016 and June 2016 (6 months intervals after factory calibration) using span calibration mixed gas specifications: $\mathrm{CO}-50 \mathrm{ppm} ; \mathrm{SO}_{2}-5 \mathrm{ppm} ; \mathrm{H}_{2} \mathrm{~S}-15 \mathrm{ppm}$; LEL $-58 \%$.

\subsection{Statistical Analysis}

The observed data were entered and analysed in Microsoft Excel 2013, SPSS version 18 and Matlab. Geo-statistical analysis was conducted using the Surfer 8 software. The day-time weighted average (Llanes, 2016) for criteria pollutants concentrations were adopted to compute the 1-year running average. The outdoor pollution exposure categories were determined using the WHO, FEPA and SANS stipulated limits.

\section{Results and Discussion}

The results highlight the weighted day-time average of criteria pollutants $\left(\mathrm{CO}, \mathrm{SO}_{2}, \mathrm{PM}_{2.5}\right.$ and $\mathrm{PM}_{10}$ ) obtained in Zaria from December 2015 - November 2016. Table 4 presents the descriptive statistics of criteria pollutants concentrations averaged across the various seasons of the study period. The 1-year averaged concentration values of criteria pollutants reveals that $\mathrm{CO}, \mathrm{SO}_{2}$, $\mathrm{PM}_{2.5}$ and $\mathrm{PM}_{10}$ recorded $29.22 \mathrm{ppm}, 0.32 \mathrm{ppm}, 219.73 \mu \mathrm{gm}^{-3}$ and $451.96 \mu \mathrm{gm}^{-3}$ respectively. The 
concentration level for observed criteria pollutants were lowest during the December-JanuaryFebruary (harmattan) season. This can be attributed to the restricted outdoor activities due low ambient temperature especially during morning and evening periods. Another factor is the windy harmattan season which quickly disperses pollutant emissions. Correlation values between the observed criteria pollutants averaged $0.985,0.988,0.988$ and 0.986 for $\mathrm{CO}, \mathrm{SO}_{2}, \mathrm{PM}_{2.5}$ and $\mathrm{PM}_{10}$. They were all significant at the 0.01 level.

Table 4. Descriptive statistics of criteria pollutants: $\mathrm{CO}, \mathrm{SO}_{2}, \mathrm{PM}_{2.5}$ and $\mathrm{PM}_{10}$ in Zaria metropolis in $2015-2016(\mathrm{~N}=19,104)$

\begin{tabular}{llccccccc}
\hline $\begin{array}{l}\text { Criteria } \\
\text { Pollutants }\end{array}$ & & Mean & SD & Median & Q1 & Q3 & Min $^{a}$ & Max \\
\hline \multirow{4}{*}{ CO $(\mathrm{ppm})$} & Whole Year & 29.22 & 28.28 & 23.0 & 12.0 & 38.0 & 0.0 & 413.0 \\
& DJF & 20.34 & 20.09 & 16.0 & 6.0 & 29.0 & 0.0 & 269.0 \\
& MAM & 34.33 & 30.20 & 28.0 & 17.0 & 42.0 & 0.0 & 407.0 \\
& JJA & 34.20 & 32.24 & 27.0 & 14.0 & 44.0 & 0.0 & 386.0 \\
& SON & 28.00 & 27.14 & 23.0 & 12.0 & 36.0 & 0.0 & 413.0 \\
& Whole Year & 0.32 & 0.26 & 0.20 & 0.10 & 0.40 & 0.0 & 3.50 \\
$\mathrm{SO}_{2}(\mathrm{ppm})$ & DJF & 0.28 & 0.25 & 0.10 & 0.10 & 0.30 & 0.0 & 1.70 \\
& MAM & 0.21 & 0.17 & 0.20 & 0.10 & 0.40 & 0.0 & 3.50 \\
& JJA & 0.37 & 0.30 & 0.30 & 0.10 & 0.50 & 0.0 & 3.20 \\
& SON & 0.42 & 0.27 & 0.40 & 0.20 & 0.60 & 0.1 & 2.80 \\
& Whole Year & 219.73 & 123.46 & 197.0 & 127.0 & 304.0 & 6.0 & $500.0^{\mathrm{b}}$ \\
$\mathrm{PM}_{2.5}\left(\mu \mathrm{gm}^{-3}\right)$ & DJF & 196.15 & 103.95 & 173.0 & 118.0 & 250.5 & 11.0 & $500.0^{\mathrm{b}}$ \\
& MAM & 216.36 & 122.09 & 197.0 & 123.0 & 300.0 & 9.0 & $500.0^{\mathrm{b}}$ \\
& JJA & 190.40 & 123.42 & 181.0 & 106.0 & 277.0 & 6.0 & $500.0^{\mathrm{b}}$ \\
& SON & 276.01 & 130.64 & 261.0 & 172.0 & 371.0 & 7.0 & $500.0^{\mathrm{b}}$ \\
& Whole Year & 451.96 & 251.42 & 403.0 & 259.0 & 615.0 & 12.0 & $1000.0^{\mathrm{b}}$ \\
& DJF & 401.82 & 213.45 & 350.0 & 243.0 & 505.0 & 16.0 & $1000.0^{\mathrm{b}}$ \\
$\mathrm{PM}_{10}\left(\mu \mathrm{gm}^{-3}\right)$ & MAM & 442.45 & 248.13 & 405.0 & 250.0 & 608.0 & 17.0 & $1000.0^{\mathrm{b}}$ \\
& JJA & 405.72 & 250.98 & 363.0 & 214.0 & 561.0 & 12.0 & $1000.0^{\mathrm{b}}$ \\
& SON & 557.58 & 265.89 & 529.0 & 349.3 & 758.0 & $18 . .0$ & $1000.0^{\mathrm{b}}$ \\
\hline
\end{tabular}

a values recorded mostly at control sites, ${ }^{\mathrm{b}}$ maximum concentration range for $\mathrm{CW}-\mathrm{HAT} 200$ particulate counter

Figure 3 displays the time-series plots of criteria pollutants for control site 6 and two other sites ( 9 and 15). Site 14 recorded the highest concentration levels for the criteria pollutants studied. This could be attributed to the site being positioned at the study area's main market. The 1-year average concentration of CO measured were above WHO stipulated limit in 16 of the 19 sample sites; FEPA limit (in 15 sample sites) and 10 sites exceeded the SANS limit. Averaged $\mathrm{SO}_{2}$ and $\mathrm{PM}_{10}$ levels were above WHO, FEPA and SANS limit in all the sampling sites. Averaged $\mathrm{PM}_{2.5}$ concentrations were also above WHO limit in all the sample sites (Nigeria's FEPA and South 
Africa's SANS guidelines do not have specified threshold for $\mathrm{PM}_{2.5}$ ); $\mathrm{PM}_{10}$ was above WHO, FEPA and SANS limit in all the sites (Figure 4). The predicted spatial distribution of criteria pollutants from the network relationship over the 19 sample sites is also displayed in Figure 4 . The pollution map process was achieved by averaging the spatio-temporal pollutant concentrations based on the Kriging function (Araki et al., 2015). This spatial pollution distribution is often used for predicting air pollutants measurements over unmeasured locations (Contreras and Ferri, 2016). 

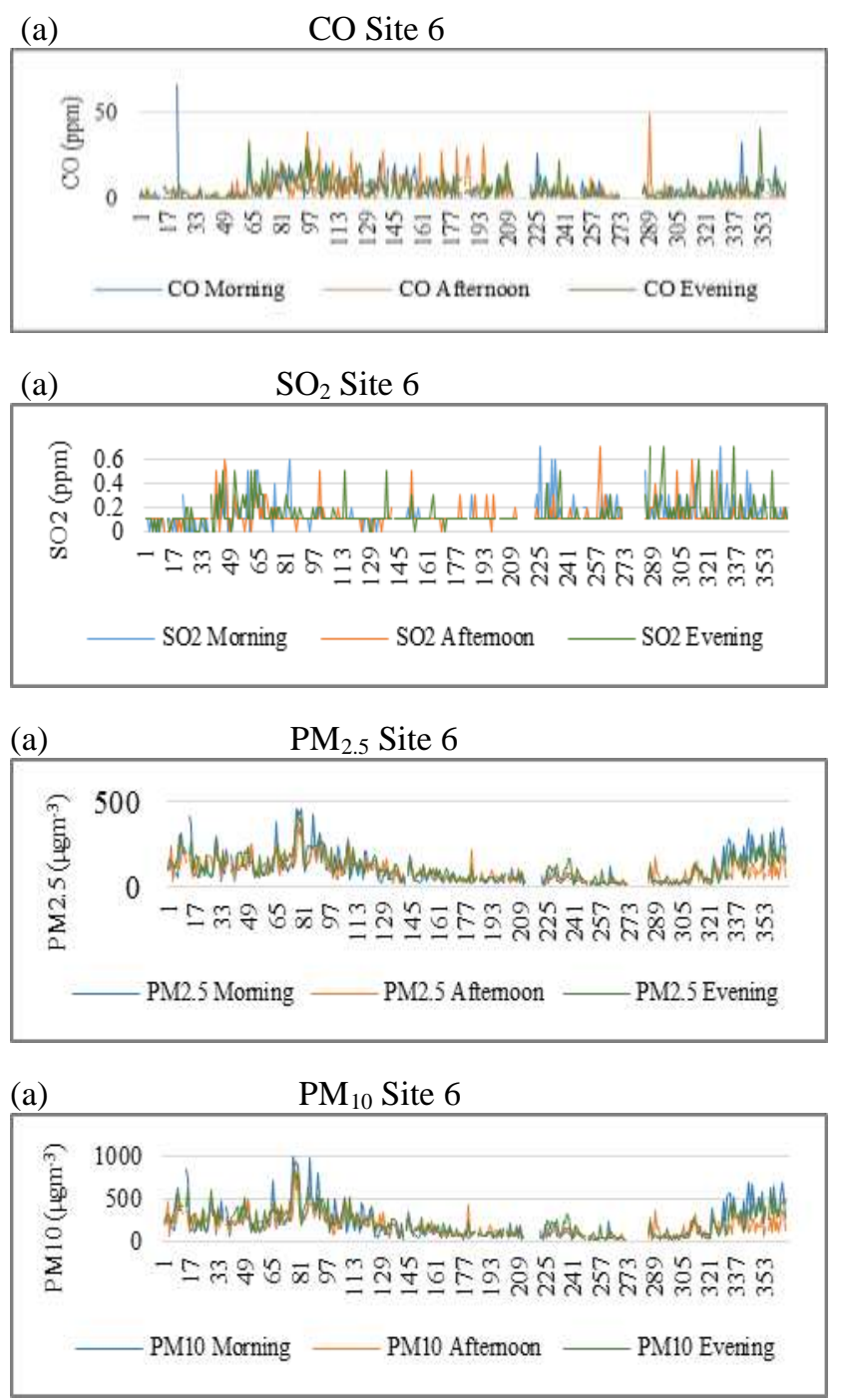

(c)

CO Site 15
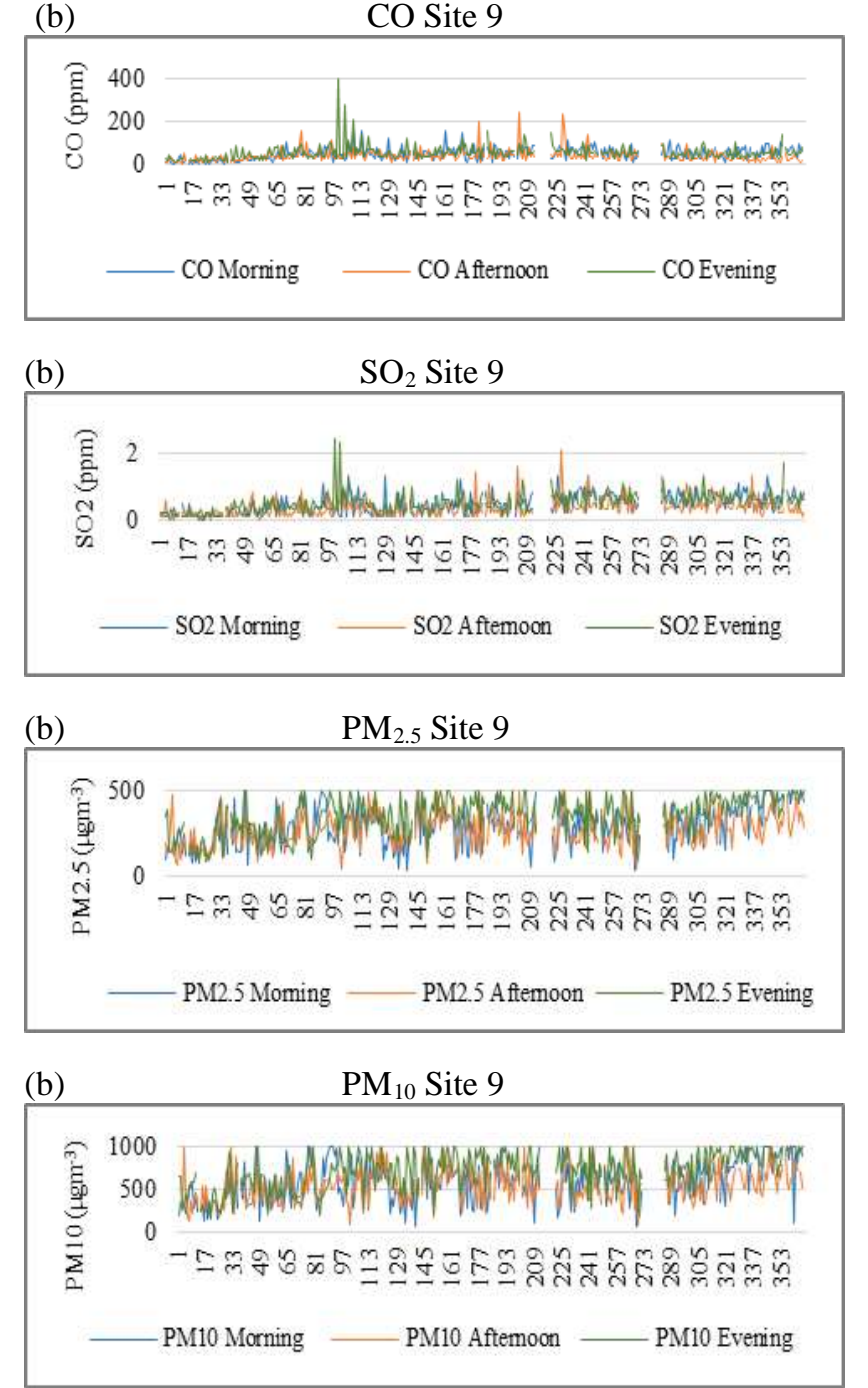

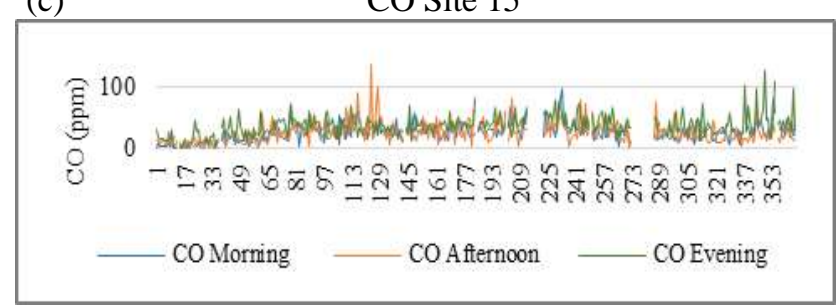

(c)

$\mathrm{SO}_{2}$ Site 15

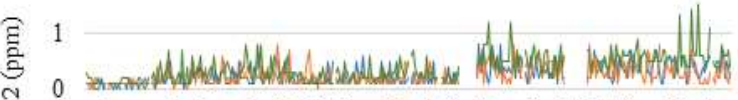

$$
\begin{aligned}
& \text { กั } \\
& \text { - SO2 Morning — SO2Aftemoon — SO2 Evening }
\end{aligned}
$$
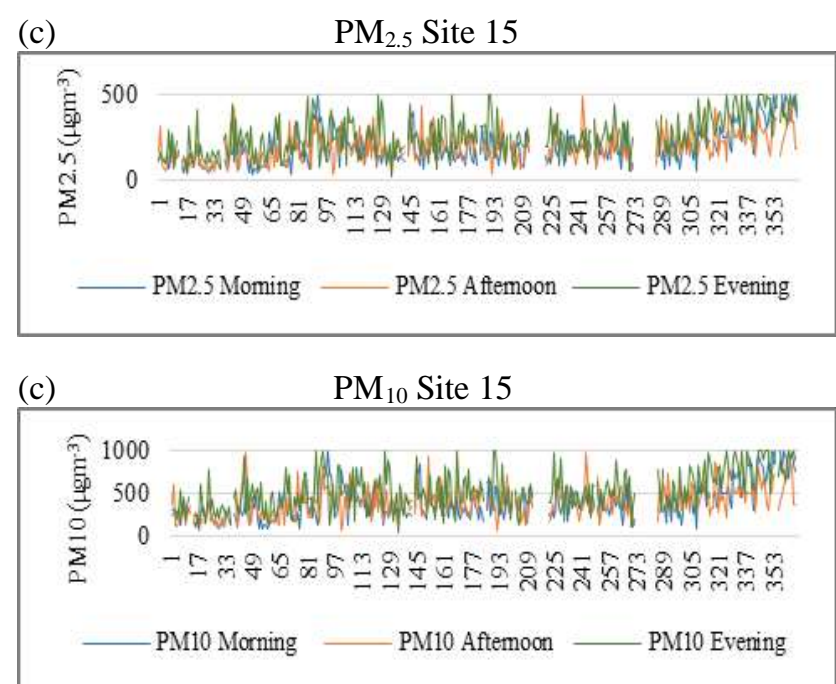

Figure 3. Time-series of criteria pollutants $\left(\mathrm{CO}, \mathrm{SO}_{2}, \mathrm{PM}_{2.5}\right.$ and $\left.\mathrm{PM}_{10}\right)$ concentrations for randomly selected (a) site 6 (b) site 9 and (c) site 15 for the 366 days of the study period 

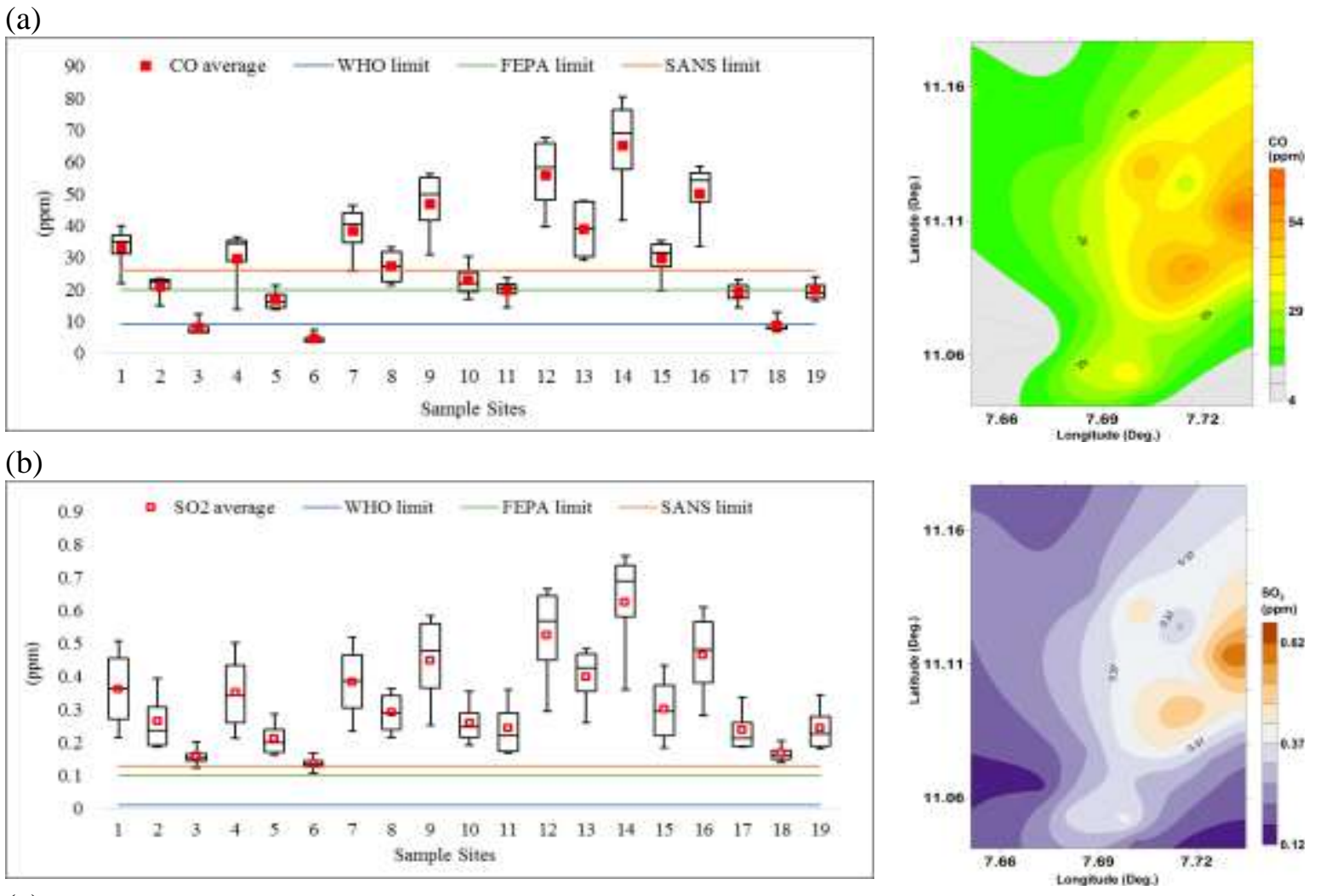

(c)
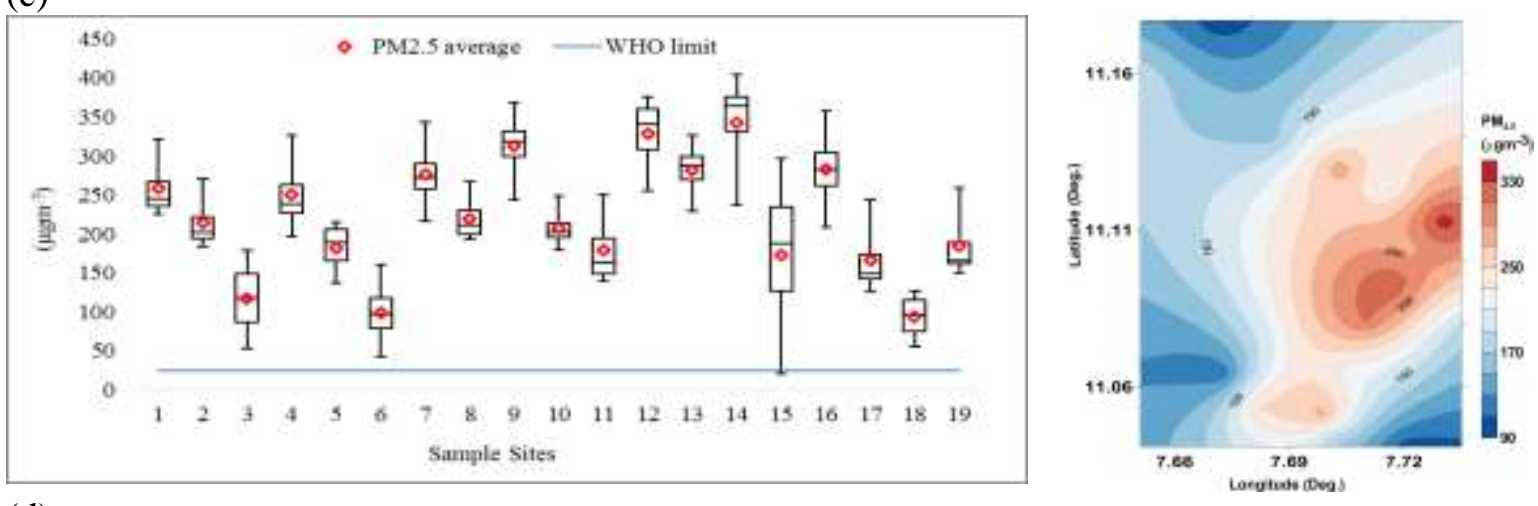

(d)
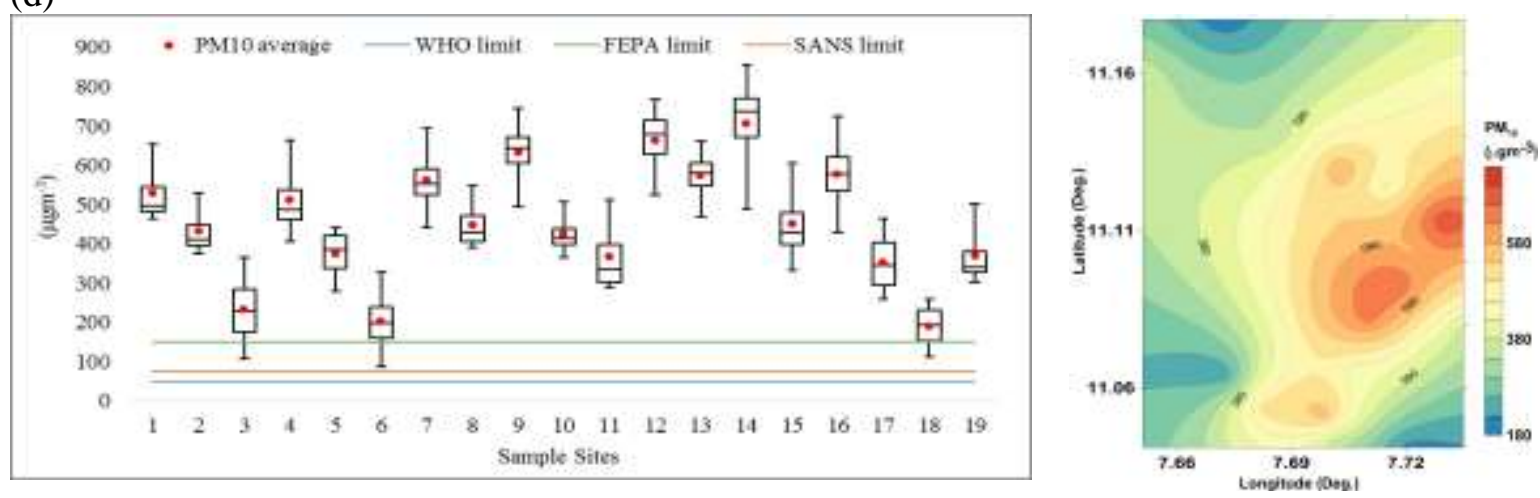

Figure 4. Box plots of pollutant concentrations from the 19 sample sites showing the performance against the WHO/FEPA/SANS stipulated limits and the predicted exposure maps in 2015 - 2016 (a) $\mathrm{CO}$ (b) $\mathrm{SO}_{2}$ (c) $\mathrm{PM}_{2.5}$ (d) $\mathrm{PM}_{10}$ (Sites 3, 6 and 18 are control sites) 
Taking into consideration, the global ambient air pollution update (WHO, 2016) in addition to the observed yearly day-time average concentration level for $\mathrm{PM}_{2.5}$ and $\mathrm{PM}_{10}$ as 219.73 and $451.96 \mathrm{gm}^{-3}$ respectively revealed by our study, we can categorically report that the study area, Zaria metropolis, is a major contender for the World's top 5 polluted cities (Figures $5 \mathrm{a}$ and b).

(a)

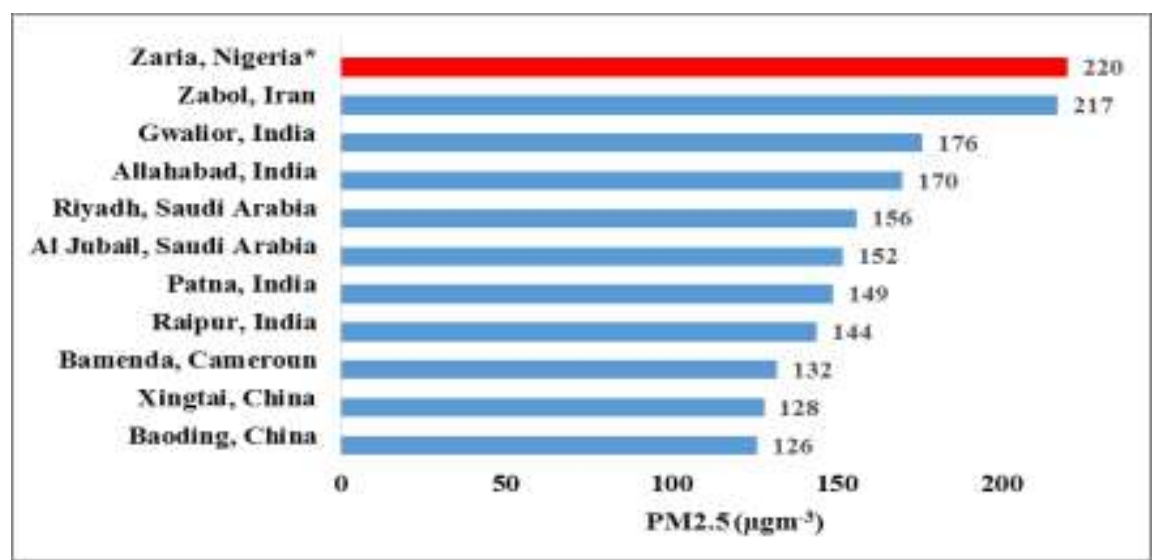

(b)

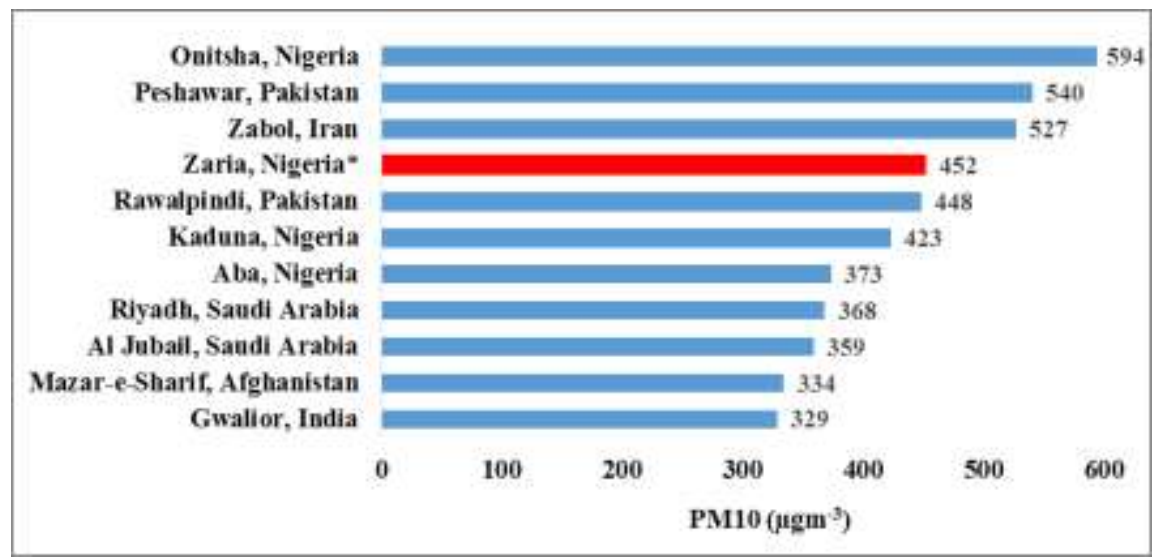

Figure 5. The 1-year weighted average of measurement $\mathrm{PM}_{2.5}$ (a) and $\mathrm{PM}_{10}$ (b) for Zaria, in contrast with the 10 most polluted cities of the World. This is modified after the (WHO 2016). *Zaria is placed in $1^{\text {st }}$ and $4^{\text {th }}$ position respectively.

\subsection{Instrument Reliability}

Studies have evaluated the reliability of these low-power and relatively low-cost pollutant sensors for air pollution monitoring application. They have been adjudged to have acceptable potential when compared to reference monitoring instruments (Walker, 2012; Lin et al., 2015; Liu et al., 2014; Mishra et al., 2015; Shibata et al., 2015; Li and Biswas, 2017). However, considering that our study area has no existing reference pollution monitoring stations, we decided to adopt 
validated theories on air pollution contribution to global warming (Hansen et al., 2000; Duan et al., 2017). We utilized the retrieved criteria pollutant concentrations for analysis with independent collocating ground air temperature and land surface temperature (LST) data for the study period. The ground air temperature data are collected using the Casella and Co. wall thermometer stationed at the Nigerian Meteorological Agency (NiMET) Zaria office, while the LST were extracted from Landsat 8. This is a unique approach. For the LST, the Landsat 8 at Path/Row 189/52 (which collocates with image tile covering the area of interest) was downloaded from the USGS website (https://earthexplorer.usgs.gov/). The criterion of Landsat 8 image file was set at cloud cover of less than 10 percent. The Landsat scene information is described in Table 5.

Table 5. Landsat image parameters which fulfilled the criteria for the study period of interest

\begin{tabular}{cccccc}
\hline $\begin{array}{c}\text { Acquisition } \\
\text { date }\end{array}$ & Scene ID & $\begin{array}{c}\text { Scene centre } \\
\text { time (GMT) }\end{array}$ & $\begin{array}{c}\text { Cloud } \\
\text { cover }(\%)\end{array}$ & $\begin{array}{c}\text { Sun } \\
\text { Azimuth } \\
\text { (deg.) }\end{array}$ & $\begin{array}{c}\text { Sun } \\
\text { elevation } \\
\text { (deg.) }\end{array}$ \\
\hline 10-Dec-15 & LC81890522015344LGN00 & $09: 49: 29$ & 4.41 & 146.47 & 48.65 \\
11-Jan-16 & LC81890522016011LGN00 & $09: 49: 27$ & 0.01 & 141.42 & 47.28 \\
12-Feb-16 & LC81890522016043LGN00 & $09: 49: 20$ & 0.03 & 130.87 & 51.81 \\
28-Feb-16 & LC81890522016059LGN00 & $09: 49: 16$ & 0.01 & 129.59 & 55.58 \\
31-Mar-16 & LC81890522016091LGN00 & $09: 49: 02$ & 7.56 & 103.26 & 62.99 \\
16-Apr-16 & LC81890522016107LGN00 & $09: 48: 57$ & 0.50 & 90.34 & 65.17 \\
02-May-16 & LC81890522016123LGN00 & $09: 49: 00$ & 5.10 & 77.74 & 65.76 \\
25-Oct-16 & LC81890522016299LGN00 & $09: 49: 44$ & 0.01 & 138.01 & 58.21 \\
10-Nov-16 & LC81890522016315LGN00 & $09: 49: 42$ & 0.00 & 143.79 & 54.37 \\
26-Nov-16 & LC81890522016331LGN00 & $09: 49: 43$ & 0.89 & 146.36 & 50.87 \\
\hline
\end{tabular}

The LST extracted from Landsat 8 OLI and TIRS images was achieved using thermal bands 10 and 11, which retrieve information at 100-meter resolution, but are resampled to 30-meter for data delivery. LST was retrieved from thermal bands 10 and 11 using ArcGIS 10.2.2 software with Equations (1-3) below.

$$
L S T=[T / 1+w \times(T / p) \times \ln (e)]
$$

where $\mathrm{T}$ is satellite brightness temperature derived from inversion of Planck's Law (Equation 2); $\mathrm{w}$ is wavelength of emittance $(11.5 \mu \mathrm{m}) ; \mathrm{p}$ is 14380 and $\mathrm{e}$ is the land surface emissivity derived from normalized vegetation difference index (NDVI). 


$$
T=\frac{K_{2}}{\ln \left(\frac{K_{1}}{L_{\lambda}}+1\right)}
$$

where $\mathrm{K}_{2}$ and $\mathrm{K}_{1}$ are the band specific thermal conversion constant for thermal bands, 1321.0789 and 774.8853 respectively; $\mathrm{L}_{\lambda}$ is top of atmosphere radiance described in Equation 3.

$$
L_{\lambda}=M_{L} \times Q_{C A L}+A_{L}
$$

where $\mathrm{L}_{\lambda}$ is top of atmosphere radiance; $\mathrm{M}_{\mathrm{L}}$ is 0.0003342 (radiance multiplicative scaling factor for thermal bands); $\mathrm{Q}_{\mathrm{CAL}}$ is the quantized digital number; $\mathrm{A}_{\mathrm{L}}$ is 0.1 (radiance additive scaling factor for thermal bands).

For improvement of reliability, the 10 LSTs days derived from the Landsat 8 thermal bands were first correlated with collocating day-time ground air temperature data and then the weighted averaged pollutant measurements. The correlation coefficient revealed compelling relationship between the Landsat 8 retrieved LST with ground air temperature and pollutant concentration (Figure 6). The analysis showed that ground air temperature and Landsat LST correlated highest as expected $(R=0.94)$, then followed by $\mathrm{PM}_{10}(\mathrm{R}=0.91)$ in Figure $6 b$. These coefficient values certified the reliability of the portable pollutant monitors.

(a)

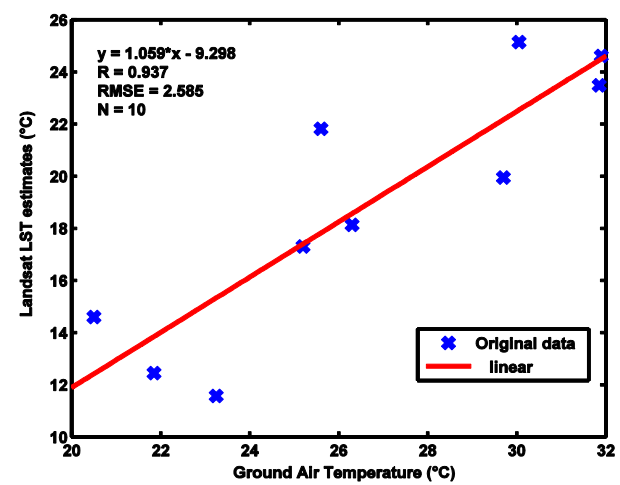

(b)

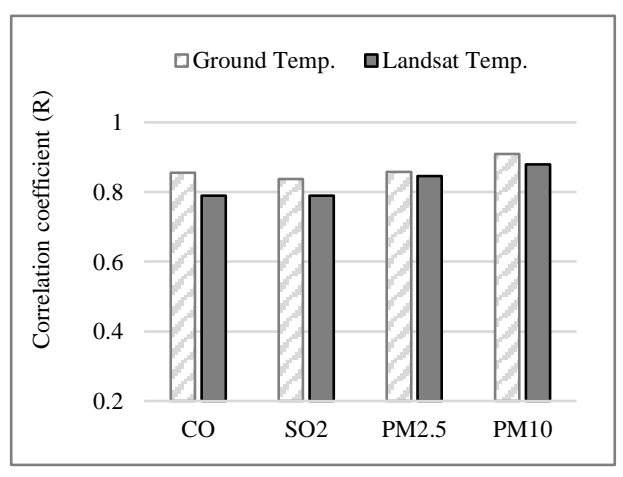

Figure 6. Correlation coefficient between (a) ground air temperatures with Landsat LST estimates; (b) observed ground pollution measurements and ground temperature/Landsat LST confirming instrument reliability

\section{Conclusions}

There is a need for Nigeria to improve on its management of air pollution. Our conclusion is based on the alarming results revealed by this study. The study revealed a one-year day-time 
weighted average of $29.22 \mathrm{ppm}$ for $\mathrm{CO}, 0.32 \mathrm{ppm}$ for $\mathrm{SO}_{2}, 219.73 \mu \mathrm{gm}^{-3}$ for $\mathrm{PM}_{2.5}$ and 451.96 $\mu \mathrm{gm}^{-3}$ for $\mathrm{PM}_{10}$. The recorded $\mathrm{PM}_{2.5}$ and $\mathrm{PM}_{10}$ pollutants sadly predicts Zaria metropolis, as a major contender for the top five of the World Health Organization's most polluted cities (Figure 5). Measured concentration levels of CO were above WHO, FEPA and SANS stipulated limit in most of the sample sites; $\mathrm{SO}_{2}, \mathrm{PM}_{2.5}$ and $\mathrm{PM}_{10}$ concentration levels were above WHO, FEPA and SANS limit in all the sites. The need for in-situ pollution data in Nigerian cities cannot be overemphasized. With the disturbing findings of this study, other fields of study that should be explored include the population health risk due to air pollution exposure and existing remote sensing capabilities for air pollution monitoring.

\section{Acknowledgements}

This study is supported by postgraduate bursary from the University of Pretoria, South Africa and the Ahmadu Bello University, Zaria, Nigeria, to the first author. We acknowledge the United States Geological Survey (USGS) for the Landsat 8 data. We also acknowledge the contribution of the anonymous reviewers.

\section{References}

Al-Awadi, L.T., Popov, V. \& Khan, A.R. 2015. Seasonal effects of major primary pollutants in Ali Sabah Al-Salem residential area in Kuwait. International Journal of Environmental Technology and Management, 18(1): 54-82.

Aliyu, Y.A., Musa, I.J. \& Jeb, D.N. 2014. Geostatistics of pollutant gases along high traffic points in urban Zaria, Nigeria. International Journal of Geomatics Geosciences, 5(1): 19-31.

Araki, S., Yamamoto, K. \& Kondo, A. 2015. Application of regression kriging to air pollutant concentrations in Japan with high spatial resolution. Aerosol and Air Quality Research, 15: 234-241.

Cairncross, E.K., John, J. \& Zunckel, M. 2007. A novel air pollution index based on the relative risk of daily mortality associated with short-term exposure to common air pollutants. Atmospheric Environment, 41: 8442-8454.

Contreras, L. \& Ferri, C. 2016. Wind-sensitive interpolation of urban air pollution forecasts. Procedia Computer Science, 80: 313-323.

DeMott, P.J., Sassen, K., Poellot, M.R., Baumgardner, D., Rogers, D.C., Brooks, S.D., Prenni, A.J. $\&$ Kreidenweis, S.M. 2003. African dust aerosols as atmospheric ice nuclei. Geophysical Research Letters, 30(14). 
Duan, K., Sun, G., Zhang, Y., Yahya, K., Wang, K., Madden, J.M., Caldwell, P.V., Cohen, E.C. \& McNulty, S.G. 2017. Impact of air pollution induced climate change on water availability and ecosystem productivity in the conterminous United States. Climatic Change, 140(2): 259-272.

FEPA (Federal Environmental Protection Agency), 1999. Nationale Environmental (Effluent Limitation) Regulations. http://www.placng.org/new/laws/F10.pdf. Last access: 15 September 2016.

Francesco, N., Tubiello, R.D., Cóndor-Golec, M., Salvatore, A.P., Sandro, F., Alessandro, F., Simone, R., Alessandro, F., Paola, C., Riccardo, B., Heather, J., Paulina, P. \& Paolo, P. 2014. Estimating Greenhouse Gas Emissions in Agriculture. A Food and Agriculture Organization (FAO) of the United Nations manual to Address Data Requirements for Developing Countries http://www.ipccnggip.iges.or.jp/public/gpglulucf/gpglulucf_files/Glossary_Acronyms_BasicInfo/Glossary. pdf. Last access: 15 March 2015.

Gorai, A.K., Tchounwou, P.B. \& Mitra, G. 2017. Spatial variation of ground level ozone concentrations and its health impacts in an urban area in India. Aerosol and Air Quality Research, 17(4): 951-964.

Grace, U.M., Sawa, B.A. \& Jaiyeoba, I.A. 2015. Multi-temporal remote sensing of landuse dynamics in Zaria, Nigeria. Journal of Environment and Earth Science, 5(9): 121-138.

Hansen, J., Sato, M., Ruedy, R., Lacis, A. \& Oinas, V. 2000. Global warming in the twenty-first century: An alternative scenario. Proceedings of the National Academy of Sciences, 97(18): 9875-9880.

Hasenfratz, D., Saukh, O., Walser, C., Hueglin, C., Fierz, M., Arn, T., Beutel, J. \& Thiele, L. 2015. Deriving high-resolution urban air pollution maps using mobile sensor nodes. Pervasive and Mobile Computing, 16: 268-285.

Hopkins, J.R., Evans, M.J., Lee, J.D., Lewis, A.C., Marsham, J.H., McQuaid, J.B., Parker, D.J., Stewart, D.J., Reeves, C. \& Purvis, R.M. 2009. Direct estimates of emissions from the megacity of Lagos. Atmospheric Chemistry and Physics, (9): 8471-8477.

Li, J. \& Biswas, P. 2017. Optical characterization studies of a low-cost particle sensor. Aerosol and Air Quality Research, 17(7): 1691-1704.

Lin, C., Gillespie, J., Schuder, M.D., Duberstein, W., Beverland, I.J. \& Heal, M.R. 2015. Evaluation and calibration of Aeroqual series 500 portable gas sensors for accurate measurement of ambient ozone and nitrogen dioxide. Atmospheric Environment, 100: 111116.

Liu, J., Man, Y. \& Liu, Y. 2014. Temporal variability of $\mathrm{PM}_{10}$ and $\mathrm{PM}_{2.5}$ inside and outside a residential home during 2014 Chinese spring festival in Zhengzhou, China. Natural Hazards, 73(3): 2149-2154. 
Llanes, S. 2016. How to calculate time-weighted average (TWA). $26^{\text {th }}$ Annual California Industrial Hygiene Council (CIHC) Conference, San Diego, http://www.thecohengroup.com/article/calculate-time-weighted-average-twa/. Last access: 07 October 2017.

Marais, E.A. \& Chance, K. 2015. A geostationary air quality monitoring platform for Africa. Clean Air Journal, 25(1): 40-45.

Marais, E.A., Jacob, D.J., Wecht, K., Lerot, C., Zhang, L., Yu, K., Kurosu, T.P., Chance, K. \& Sauvage, B. 2014. Anthropogenic emissions in Nigeria and implications for atmospheric ozone pollution: A view from space. Atmospheric Environment, 99: 32-40.

Mishra, R.K., Joshi, T., Goel, N., Gupta, H. \& Kumar, A. 2015. Monitoring and analysis of PM10 concentration at Delhi Metro construction sites. International Journal of Environment and Pollution, 57(1-2): 27-37.

NPC (National Population Commission), 2010. Population distribution by sex, state, LGA, senatorial district, 2006 population and housing census. http://www.population.gov.ng/images/NPCNEW/Pr\%20Vol\%203\%20Pop\%20by\%20State \%20\&\%20Senatoria1\%20District.zip. Last access: 16 December 2016.

Nsubuga, F.N.W., Olwoch, J.M. \& Rautenbach, H. 2013. Variability procedures for daily and monthly observed near-surface temperatures in Uganda. International Journal of Climatology, 34(2): 303-314.

Pattinson, W., Longley, I. \& Kingham, S. 2014. Using mobile monitoring to visualise diurnal variation of traffic pollutants across two near-highway neighbourhoods. Atmospheric Environment, 94: 782-792.

Patton, A.P., Laumbach, R., Ohman-Strickland, P., Black, K., Alimokhtari, S., Lioy, P.J. \& Kipen, H.M. 2016. Scripted drives: A robust protocol for generating exposures to traffic-related air pollution. Atmospheric Environment, 143: 290-299.

SANS (South African National Standards), 2011. Ambient air quality - limits for common pollutants, https://law.resource.org/pub/za/ibr/za.sans.1929.2011.pdf. Last access: 07 October 2015.

Shibata, T., Wilson, J.L., Watson, L.M., Nikitin, I.V., La Ane, R. \& Maidin, A. 2015. Life in a landfill slum, children's health, and the millennium development goals. Science of the Total Environment, 536: 408-418.

Walker, S. 2012. Keeping Mineworkers Safe. Engineering and Mining Journal, 213(2): 42.

Wang, Y., Li, J., Cheng, X., Lun, X., Sun, D. \& Wang, X. 2014. Estimation of PM10 in the trafficrelated atmosphere for three road types in Beijing and Guangzhou, China. Journal of Environmental Science, 26(1): 197-204. 
WHO, (World Health Organization), 2016. Global urban ambient air pollution database update, http://www.who.int/phe/health_topics/outdoorair/databases/WHO_AAP_database_May201 6_v3web.xlsx?ua=1. Last access: 07 September 2016.

WHO (World Health Organization), 2017. Evolution of WHO air quality guidelines. Past, present and future, http://www.euro.who.int/_data/assets/pdf_file/0019/331660/Evolution-airquality.pdf. Last access: 26 September 2017.

Yazdi, M.N., Delavarrafiee, M. \& Arhami, M. 2015. Evaluating near highway air pollutant levels and estimating emission factors: Case study of Tehran, Iran. Science of the Total Environment, 538: 375-384. 